\title{
LIVER TRANSPLANTATION AND EXPANDED MILAN CRITERIA. Does it really work?
}

\author{
Marina Vilela Chagas FERREIRA, Eleazar CHAIB, Maurício Ursoline do NASCIMENTO, \\ Rafael Souza Fava NERSESSIAN, Daniel Takeshi SETUGUTI and \\ Luiz Augusto Carneiro D’ALBUQUERQUE
}

\begin{abstract}
Context - Orthotopic liver transplantation is an excellent treatment approach for hepatocellular carcinoma in well-selected candidates. Nowadays some institutions tend to Expand the Milan Criteria including tumor with more than $5 \mathrm{~cm}$ and also associate with multiple tumors none larger than $3 \mathrm{~cm}$ in order to benefit more patients with the orthotopic liver transplantation. Methods - The data collected were based on the online database PubMED. The key words applied on the search were "expanded Milan criteria" limited to the period from 2000 to 2009. We excluded 19 papers due to: irrelevance of the subject, lack of information and incompatibility of the language (English only). We compiled patient survival and tumor recurrence free rate from 1 to 5 -years in patients with hepatocellular carcinoma submitted to orthotopic liver transplantation according to expanded the Milan criteria from different centers. Results - Review compiled data from 23 articles. Fourteen different criteria were found and they are also described in detail, however the University of California - San Francisco was the most studied one among them. Conclusion - Expanded the Milan criteria is a useful attempt for widening the preexistent protocol for patients with hepatocellular carcinoma in waiting-list for orthotopic liver transplantation. However there is no significant difference in patient survival rate and tumor recurrence free rate from those patients that followed the Milan criteria.
\end{abstract}

HEADINGS - Liver transplantation. Carcinoma, hepatocellular. Patient selection. Expanded Milan criteria.

\section{INTRODUCTION}

Orthotopic liver transplantation (OLT) is an excellent approach for hepatocellular carcinoma (HCC) in well-selected candidates ${ }^{(8,47)}$. The most widely used criteria for patient selection are those proposed by Mazzaferro et al. ${ }^{(39)}$, the so-called Milan criteria (MC), (a single tumor up to $5 \mathrm{~cm}$ or up to 3 tumors none larger than $3,0 \mathrm{~cm}$ ).

When MC were applied there was a significant improvement in survival over time for HCC patients undergoing OLT with a 5-year survival of $61,1 \%$ contrasting with previously observed 5-year survival rate of $25,3 \%$ in 1987.

In recent years, however, some groups have argued that the MC are too restrictive, and exclude some HCC-patients from OLT despite the possibility of benefit. Expanded criteria can be defined by the use of OLT in recipients with tumors beyond the MC. The first description was published in 2001 by the group of the University of California ${ }^{(63)}$. In their study, 70 HCC-patients who underwent OLT were retrospectively evaluated on the basis of explants analysis, not pre-transplant radiology. In the 60 cases with either a single nodule up to $6.5 \mathrm{~cm}$, or up to three nodules none larger than 4.5 $\mathrm{cm}$, and total tumor diameter no more than $8 \mathrm{~cm}$ the 5 -years overall survival was $75.2 \%$. Forty-six out of the 60 patients $(76 \%)$ had tumors that were within the MC and these had a 5 -year survival of $72 \%$.

Subsequently, in the past 10 years, some major new criteria was created expanding Milan criteria (EMC) such as: University of California, San Francisco (UCSF) Criteria ${ }^{(63)}$, Kyoto ${ }^{(57)}$, Asian ${ }^{(26)}$, Shanghai ${ }^{(13)}$, and others.

Our aim is to study the current situation of these several EMC proposed in order to clarify both this debate through a critical analysis of available data and addressed discussion of further parameters beyond number and size of tumors, focusing on patient survival rate and tumor recurrence free rate from 1 to 5-years after OLT.

\section{METHODS}

A systematic search of Medline (PubMED) database was performed to identify studies evaluating 
expanded criteria for patients with HCC submitted to liver transplantation. The search was restricted to papers written in English and published from 2000 to 2009. The keywords used were hepatocellular carcinoma, liver transplantation, expanded criteria, the UCSF criteria, Milan Criteria, and others. Only papers reporting cadaveric liver donors that evaluated expanded criteria on the basis of tumor number and size were selected. This search resulted in a total of 39 studies. Additionally, a full manual search from bibliographies of papers describing aspects beyond tumor number and size, and reports of consensus conference was also performed. Nineteen papers were excluded due to: irrelevance of subject, lack of information and incompatibility of language.

We compiled data focusing on patient survival rate and tumor recurrence free rate from 1 to 5 -years. We also compared results between MC and EMC. A $P<0.05$ was considered statistic significant.

\section{RESULTS}

Twenty-three papers including centers from North and South America, Europe and Asia were compiled. Fourteen different EMC were found; however UCSF was the most studied $^{(10,11,13,26,57,63)}$. The patient survival rate and tumor recurrence-free rates from 1 to 5 -years were shown in Table 1.

We have shown the UCSF patient survival and tumor recurrence-free rates from 1 to 5 -years comparing them with $\mathrm{MC}$ in Table 2. No significance difference was found between the two groups.

\section{DISCUSSION}

$\mathrm{HCC}$ is a major health problem worldwide ${ }^{(31)}$. In the West $30 \%-40 \%$ of HCC cases are detected at early stages and treated with intention to cure, a figure that reaches $60 \%$ of the cases

TABLE 1. Comparison of patient survival rate and tumor recurrence free rate among different expanded Milan criteria in the literature

\begin{tabular}{|c|c|c|c|c|c|c|c|}
\hline Author & Year & $\mathbf{N}$ & Criteria & $1 y$ & $3 y$ & $5 y$ & Staging \\
\hline Mazzaferro et al. ${ }^{(38)}$ & 2009 & 283 & $\begin{array}{l}\text { Up-to-seven: in the absence of microvascular invasion, fulfilled } \\
\text { the so-called up-to-seven criteria, with seven being the result } \\
\text { of the sum of size (in } \mathrm{cm} \text { ) and number of tumors for any given } \\
\text { hepatocellular carcinoma }\end{array}$ & & $77.7 \%$ & $71.2 \%$ & $\mathrm{P}$ \\
\hline Fan J, et al. ${ }^{(13)}$ & 2009 & 176 & $\begin{array}{l}\text { Single tumor } \leq 9 \mathrm{~cm} \text { in diameter, } 2-3 \text { tumors with the largest } \\
\leq 5 \mathrm{~cm} \text {, a total tumor diameter } \leq 9 \mathrm{~cm} \text { without macrovascular } \\
\text { invasion, lymph node invasion and extrahepatic metastasis }\end{array}$ & $\begin{array}{l}82.7 \% / \\
51.2 \%{ }^{2}\end{array}$ & - & $\begin{array}{l}75.9 \% / \\
46.1 \%{ }^{2}\end{array}$ & $\mathrm{P}$ \\
\hline Li J, et al. ${ }^{(27)}$ & 2009 & 25 & $\begin{array}{l}\text { Total tumor size } \leq 9 \mathrm{~cm} \text { and who were without macrovascular } \\
\text { invasion or extrahepatic metastases, regardless of the number of } \\
\text { tumor lesions }\end{array}$ & $\begin{array}{l}85,2 \% 1 \\
95.0 \%{ }^{2}\end{array}$ & - & $\begin{array}{l}48,4 \% 1 \\
70.4 \%{ }^{2}\end{array}$ & $\mathrm{P}$ \\
\hline Takada Y, et al. ${ }^{(58)}$ & 2010 & 23 & $\begin{array}{l}\text { Diameter } \leq 5 \mathrm{~cm} \text {; number of lesions } \leq 10 ; \text { PIVKA-II } \leq 400 \\
\mathrm{mAU} / \mathrm{mL}\end{array}$ & - & - & $95 \%{ }^{2}$ & $\mathrm{R}$ \\
\hline Boin, et al. ${ }^{(3)}$ & 2008 & 19 & Any tumor beyond Milan Criteria & - & - & $\begin{array}{l}47.4 \% \\
(10 y)\end{array}$ & $\mathrm{P}$ \\
\hline Lee SG, et al. ${ }^{(26)}$ & 2008 & 22 & $\begin{array}{l}\text { Largest tumor diameter } \leq 5 \mathrm{~cm}, \text { HCC number } \leq 6 \text {, no gross } \\
\text { vascular invasion }\end{array}$ & $100 \%$ & $88.9 \%$ & $80 \%$ & $\mathrm{P}$ \\
\hline Majeed, et al. ${ }^{(35)}$ & 2008 & 23 & $\begin{array}{l}\text { No extrahepatic evidences of spread on abdomen computed } \\
\text { tomography (CT) and chest }\end{array}$ & - & $\begin{array}{l}50 \%- \\
70 \%\end{array}$ & - & NA \\
\hline Silva, et al. ${ }^{(53)}$ & 2008 & $26 /$ & $\begin{array}{l}\text { Up to } 3 \text { nodules, with none larger than } 5 \mathrm{~cm} \text {, and a cumulative } \\
\text { tumor burden } \leq 10 \mathrm{~cm}\end{array}$ & $\begin{array}{l}92 \% 1 \\
74 \% *\end{array}$ & $\begin{array}{l}79 \% 1 \\
55 \% *\end{array}$ & $\begin{array}{l}69 \% 1 \\
40 \% *\end{array}$ & $\mathrm{R} / \mathrm{P}$ \\
\hline Herrero, et al. ${ }^{(19)}$ & 2008 & 24 & Any tumor beyond Milan Criteria & $92 \%$ & $78 \%$ & $73 \%$ & $\mathrm{R}$ \\
\hline Onaca, et al. ${ }^{(42)}$ & 2007 & 130 & $\begin{array}{l}2-4 \text { tumors with the largest } \leq 5 \mathrm{~cm} \text { or a single tumor up } \\
\text { to } 6 \mathrm{~cm}\end{array}$ & - & - & $\begin{array}{l}64.6 \%{ }^{2} \\
/ \mathrm{NA}\end{array}$ & $\mathrm{P}$ \\
\hline Soejima, et al. ${ }^{(54)}$ & 2007 & 40 & $\begin{array}{l}\text { Without extrahepatic spread or macroscopic vascular invasion. } \\
\text { The size and number of HCC nodules were not limited }\end{array}$ & $83 \%{ }^{2}$ & $74 \%{ }^{2}$ & - & $\mathrm{R}$ \\
\hline Todo, et al. ${ }^{(61)}$ & 2007 & 272 & Any tumor beyond Milan Criteria & - & - & $66.4 \%^{2}$ & $\mathrm{P}$ \\
\hline Takada, et al. ${ }^{(57)}$ & 2007 & 33 & $\leq 10$ tumors and all $\leq 5 \mathrm{~cm}$ & - & - & $93 \%{ }^{2}$ & $\mathrm{R}$ \\
\hline Hwang, et al. ${ }^{(20)}$ & 2005 & 62 & Any tumor beyond Milan Criteria & - & $62.6 \%$ & - & $\mathrm{P}$ \\
\hline Kneteman, et al. ${ }^{(25)}$ & 2004 & 21 & 1 nodule $<7.5 \mathrm{~cm}$ any number $<5 \mathrm{~cm}$ & $90.5 \%$ & - & $\begin{array}{r}83 \% \\
(4 y)\end{array}$ & $\mathrm{R}$ \\
\hline Todo, et al..$^{(61)}$ & 2007 & 171 & Any tumor beyond Milan Criteria & $\begin{array}{l}75 \% 1 \\
64.9 \% \%^{2}\end{array}$ & $\begin{array}{l}60.4 \% 1 \\
52.6 \%{ }^{2}\end{array}$ & - & NA \\
\hline Roayaie, et al. ${ }^{(45)}$ & 2002 & 32 & 1 or more nodules 5 to $7 \mathrm{~cm}$ & - & - & $55 \%^{2}$ & $\mathrm{R}$ \\
\hline
\end{tabular}

$\mathrm{n}=$ number of patients transplanted during each study

Staging refers to the method used for tumor staging $=\mathrm{P}=$ pretransplant radiology; $\mathrm{R}=$ explant tumor pathology; NA = not available

* pathology based // 2 Recurrence free rate 
TABLE 2. Comparison of patient survival rate and tumor recurrence free rate between University of California San Francisco (UCSF) and Milan Criteria

\begin{tabular}{|c|c|c|c|c|c|c|c|c|c|c|c|}
\hline \multirow[b]{3}{*}{ Author (year), Institute } & \multirow{2}{*}{\multicolumn{2}{|c|}{$\mathrm{n}$}} & \multirow{3}{*}{ Staging $(\mathbf{P})$} & \multicolumn{4}{|c|}{3 -year } & \multicolumn{4}{|c|}{ 5-year } \\
\hline & & & & \multicolumn{2}{|c|}{ UCSF } & \multicolumn{2}{|c|}{ Milan } & \multicolumn{2}{|c|}{ UCSF } & \multicolumn{2}{|c|}{ Milan } \\
\hline & UCSF & Milan & & PS & RR & PS & RR & PS & RR & PS & RR \\
\hline Yao, et al. $(2001)^{(63)}$ & 14 & 46 & - & - & - & - & - & $73 \%$ & - & $72 \%$ & - \\
\hline \multirow[t]{2}{*}{ Decaens T, et al. $(2006)^{(10)}$} & 44 & 279 & $\mathrm{R}(0.10)^{\mathrm{ITT}} /(0.14)^{2}$ & - & - & - & - & $45.60 \%{ }^{\text {ITT }}$ & $47.80 \%$ & $60.10 \%{ }^{\text {ITT }}$ & $60.40 \%$ \\
\hline & 39 & 184 & $\mathrm{P}(0.33) ¥ /(0.26)^{2}$ & - & - & - & - & $63.60 \%$ & $62.70 \%$ & $70.40 \%$ & $70.20 \%$ \\
\hline Yao, et al. $(2007)^{(66)}$ & 38 & 130 & $\mathrm{R}(0.58)^{2}$ & - & & - & - & $82 \%$ & $93.60 \%$ & $80 \%$ & $90.10 \%$ \\
\hline \multirow[t]{2}{*}{ Duffy, et al. $(2007)^{(11)}$} & 185 & 173 & $\mathrm{R}(0.061)$ & $74 \%$ & - & - & - & $64 \%$ & - & $79 \%$ & - \\
\hline & 208 & 126 & $\mathrm{P}(0.057)$ & $83 \%$ & - & - & - & $71 \%$ & - & $86 \%$ & - \\
\hline Lee SG, et al. $(2008)^{(26)}$ & 10 & 152 & $\mathrm{P}(0.953)$ & $90 \%$ & - & - & - & $78.80 \%$ & - & $76 \%$ & - \\
\hline Xiao L, et al. (2009) & 32 & 68 & $\mathrm{P}(0.058) ¥ /(0.103)^{2}$ & $55.2 \%$ & $40 \%$ & $88.40 \%$ & $81.80 \%$ & - & - & - & - \\
\hline
\end{tabular}

in Japan ${ }^{(31)}$. Surgical treatments are accepted as the standard of care for early tumors because they provide survival rates consistently better than their untreated counterparts (5-years survival rates of $40 \%-70 \%$ vs $<20 \%)^{(6,31,33,34)}$. Resection of single tumors in patients with well-preserved liver function lead to remarkable outcomes (5-years survival exceeds $50 \%$ $60 \%)^{(34)}$. Early results after OLT in unselected patients with cirrhosis and $\mathrm{HCC}$ were poor, with early recurrence rates and 5 -year survival of only $18 \%-49 \%(15,21,30,37,41,43,44,46)$. Several small studies in the early 1990s suggested that recurrence-free survival could be improved by restricting transplantation to patients with two-three nodules or a single tumor $<3-5 \mathrm{~cm}$ in diameter ${ }^{(1,14,51)}$. Two large retrospective studies ${ }^{(21,24)}$ confirmed that tumors $>5 \mathrm{~cm}$ had a high rate of post-transplantation recurrence, largely because of the association with vascular invasion and poor differention.

The MC is considered the gold standard for selection of the best HCC candidates for OLT after numerous external validations of the seminal proposed ${ }^{(39)}$. In fact, the $\mathrm{MC}$ as a restriction selection for patients with $\mathrm{HCC}$ have been confirmed as consistent by several other groups among more than 1,000 patients $^{(2,22,29)}$. The MC were subsequently used by the United Network for Organ Sharing to assign the listing priority of patients presenting HCC.

On the other hand, some studies have recently suggested that the MC might be too restrictive, with relatively good results achieved when different proposals are used (Table 1).

There are essential aspects that should be considered when treatments related to HCC are evaluate: (1) treatments that achieve survival rates higher than $50 \%$ in 5 -years are considered effectives therapies, given the fact that studies have demonstrated the 3-years survival of early HCC to be about $50 \%(5,32) ;(2)$ the deleterious impact of the progressive increase in the waiting list time has to be considered when the efficacy of OLT as a treatment for HCC is evaluated because of the risk of tumor progression and death during this period ${ }^{(33,63)}$, and (3) it is well known that preoperative imaging techniques underestimated $\mathrm{HCC}$ staging in about $20 \%$ of cases, and thus the extrapolation of the histopathologic data to the preoperative scenario might be misleading ${ }^{(7)}$.

Yao et al. ${ }^{(64)}$ from UCSF, reported a 5-year survival of $75 \%$ in patients with single tumor as large as $6.5 \mathrm{~cm}$ or a maximum of three tumors up to $4.5 \mathrm{~cm}$ and a cumulative tumor burden $<8 \mathrm{~cm}$. With mostly retrospective data, some groups have independently tested these criteria ${ }^{(10,11,37)}$. These results have, however, been challenged because of the use of explants pathology, rather than preoperative imaging, as a determinant for the definition of the tumor stage.

The UCSF proposal is the approach mostly tested; however, it has been challenged because of the use of explants pathology. Duffy et al. ${ }^{(11)}$ and Yao et al. ${ }^{(64)}$ recently published their results analyzing the survival rates and recurrence probabilities on the basis of the pre-OLT radiologic assessment.

Expansion of tumor criteria for transplantation risks including patients with higher-grade tumors or microvascular invasion who might have a higher risk of recurrence. Indeed, as observed in previous reports, we found that tumors that exceeded the MC criteria were more likely to have evidence of vascular invasion in the explants ${ }^{(21,24)}$. However, interestingly, this finding only affected recurrence-free survival when there were $>$ five tumors or a single tumor $>6 \mathrm{~cm}$. Thus, this may reflect tumor mass and the degree of vascular invasion rather than the presence of vascular invasion itself.

Several studies have shown that some tumor patients trans-

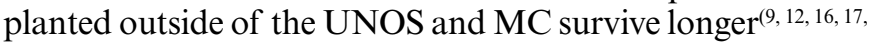
$18,36,44,52)$ and as consequence, several proposals have been made to expand the HCC inclusion criteria ${ }^{(18,28,63,64,65)}$. However, the criteria proposed by the University of Pittsburgh and some groups in Europe are based, at least in part, on pathological features (nodal invasion, grade, vascular invasion) that are not usually available before transplantation ${ }^{(9,21,50,68)}$. By contrast, the MC, UCSF and Onaca et al. ${ }^{(42)}$ proposal rely on factors (tu- 
mor size and number) that can be determined by preoperative imaging, however, such criteria must consider the limitations of imaging studies ${ }^{(7,23,48,55,56,59,60)}$. The continued improvement in imaging techniques may decrease the gap between imaging and pathology of $\mathrm{HCC}$, although some understanding will certainly continue to exist ${ }^{(53)}$.

Silva et al. ${ }^{(54)}$ reported 281 cases of HCC in cirrhotic livers treated by OLT using a new criteria (up to three tumors, each no larger than $5 \mathrm{~cm}$, and a cumulative tumor burden $<10 \mathrm{~cm}$ ) with a 5-year survival rate of $57 \%$ based on the intention-to-treat principle. The 5-year survival rate was $63 \%$ among transplanted patients.

No difference in survival or in recurrence were found between cases within and beyond the UCSF criteria and others. Although these results suggest that this expansion does not result in an impaired outcome, we understand that they need validation, given the relatively small number of patients. Microvascular invasion was the only factor that predicted poor survival in the multivariate analysis. Indeed, several studies have shown that the differentiation degree and microvascular invasion represent direct indicators of the biologic progression of HCC, being associated with tumor recurrence and poor long-term survival ${ }^{(9,11,18,39,40,45)}$.

Expansion of transplantation inclusion criteria should be made cautiously. Listing criteria for HCC should reflect the minimum acceptable recurrence-free survival rate and must reflect a consensus of transplantation community. Furthermore, the results need to be confirmed prospectively if criteria were liberalized to ensure that an unrecognized selection bias did not influence the results themselves. Finally, the societal benefit of expanding tumor criteria needs to be weighed against a relatively fixed donor organ supply and a growing demand for OLT for other indications, such as decompensated cirrhosis due to chronic hepatitis $\mathrm{C}$, where long-term survival may be better.

In conclusion, the EMC is useful attempt for widening the preexistent protocol for patients with HCC in the waiting-list for OLT, however there is no significant difference in patient survival rate and tumor recurrence free rate from those patients that followed the MC.

Ferreira MVC, Chaib E, Nascimento MU, Nersessian RSF, Setuguti DT, D’Albuquerque LAC. Transplante de fígado e critérios de Milão expandidos. Isto realmente funciona? Arq Gastroenterol. 2012;49(3):189-94.

RESUMO - Contexto - Em pacientes bem selecionados, o transplante ortotópico de fígado é um excelente tratamento para pacientes com carcinoma hepatocelular. Algumas instituições atualmente tendem a expandir os critérios de Milão. São os chamados Critérios de Milão Expandidos, que incluem tumores maiores do que $5 \mathrm{~cm}$ e também aqueles associados com múltiplos tumores, não maiores do que $3 \mathrm{~cm}$, a fim de beneficiar o maior número possível de pacientes submetidos ao transplante ortotópico de fígado. Métodos - Os dados foram coletados na base de dados do PubMED. A palavra-chave para procura foi Critérios de Milão expandidos, no período de 2000 a 2009. Foram excluídos 19 trabalhos devido à falta de dados de sobrevida e à recurrência tumoral, não compatíveis com a língua inglesa e fora do assunto em questão. Foram analisadas a sobrevida do paciente e a taxa de recurrência do tumor de 1 a 5 anos de pacientes submetidos ao transplante hepático com critérios de Milão expandidos em diferentes centros internacionais. Resultados Esta revisão agregou 23 trabalhos. Catorze diferentes critérios foram encontrados e descritos em detalhes. No entanto, os critérios da Universidade da Califórnia em São Francisco foram os mais estudados entre todos os analisados. Conclusão - Os Critérios de Milão Expandidos são úteis para ampliar os protocolos para adesão de doentes na lista de espera para transplante de fígado, não havendo diferença significante na sobrevida do doente e nem na taxa livre de recurrência tumoral quando comparados aos critérios de Milão.

DESCRITORES - Transplante de fígado. Carcinoma hepatocelular. Seleção de pacientes. Critério de Milão expandido. 


\section{REFERENCES}

1. Bismuth H, Chiche L, Adam R, Castaing D, Diamond T, Dennison A. Liver resection versus transplantation for hepatocellular carcinoma in cirrhotic patients. Ann Surg. 1993;218:145-51.

2. Bismuth H, Majno PE, Adam R. Liver transplantation for hepatocellular carcinoma. Semin Liver Dis. 1999;19:311-22.

3. Boin IF, Pracucho EM, Rique MC, Reno RR, Robertoni DB, Silva PV, Rosim ET, Soares AB, Escanhoela CA, Leonardi MI, Souza JR, Leonardi LS. Expanded Milan criteria on pathological examination after liver transplantation: analysis of preoperative data. Transplant Proc. 2008;40:777-9.

4. Bruix J, Fuster J, Llovet JM. Liver transplantation for hepatocellular carcinoma: Foucault pendulum versus evidence-based decision. Liver transpl. 2003;9:700-2.

5. Bruix J, Llovet JM. Prognostic prediction and treatment strategy in hepatocellular carcinoma. Hepatology. 2002;35:519-24.

6. Bruix J, Sherman N, Llovet JM, Beaugrand M, Lencioni R, Burroughs AK, Christensen E, Pagliaro L, Colombo M, Rodés J; EASL panel of Experts on HCC. Clinical management on hepatocellular carcinoma. Conclusions of the Barcelona-2000 EASL Conference. J Hepatol. 2005;35:421-30.

7. Burrel M, Llovet JM, Ayuso C, Iglesias C, Sala M, Miquel R, Caralt T, Ayuso JR, Solé M, Sanchez M, Brú C, Bruix J; Barcelona Clínic Liver Cancer Group. MRI angiography is superior to helicoidal CT for detection of HCC prior liver transplantation: an explants correlation. Hepatology. 2003;38:1034-42.

8. Busuttil RW, Farmer DG, Yersiz H, Hiatt JR, McDiarmid SV, Goldstein LI, Saab S, Han S, Durazo F, Weaver M, Cao C, Chen T, Lipshutz GS, Holt C, Gordon S, Gornbein J, Amersi F, Ghobrial RM. Analysis of long-term outcomes of 3200 liver transplantations over two decades: a single center experience. Ann Surg. 2005;241:905-16

9. Cillo U, Vitale A, Bassanello M, Boccagni P, Brolese A, Zanus G, Burra P, Fagiuoli S, Farinati F, Rugge M, D'Amico DF. Liver transplantation for the treatment of moderately or well-differentiation hepatocellular carcinoma. Ann Surg. 2004;239:150-9.

10. Decaens T, Roudot-Thoraval F, Hadni-Bresson S, Meyer C, Gugenheim J, Durand F, Bernard PH, Boillot O, Sulpice L, Calmus Y, Hardwigsen J, Ducerf C, Pageaux GP, Dharancy S, Chazouilleres O, Cherqui D, Duvoux C. Impact of UCSF criteria according to pre- and post-OLT tumor features: analysis of 479 patients listed for HCC with a short waiting time. Liver Transpl. 2006;12:1761-9.

11. Duffy JP, Vardanian A, Benjamin E, Watson M, Farmer DG, Ghobrial RM, Lipshutz G, Yersiz H, Lu DS, Lassman C, Tong MJ, Hiatt JR, Busuttil RW. Liver transplantation criteria for hepatocellular carcinoma should be expanded: a 22-year experience with 467 patients at UCLA. Ann Surg. 2007;246:502-9.

12. Durand F, Belguiti J. Liver transplantation for hepatocellular carcinoma: should we push the limits? Liver Transpl. 2003;9:697-9.

13. Fan J, Yang GS, Fu ZR, Peng ZH, Xia Q, Peng CH, Qian JM, Zhou J, Xu Y, Qiu SJ, Zhong L, Zhou GW, Zhang JJ. Liver transplantation outcomes in 1,078 hepatocellular carcinoma patients: a multi-center experience in Shanghai, China. J Cancer Res Clin Oncol. 2009;135:1403-12.

14. Figueras J, Jaurrieta E, Valls C, Benasco C, Rafecas A, Xiol X, Fabregat J, Casanovas T, Torras J, Baliellas C, Ibañez L, Moreno P, Casais L. Survival after liver transplantation in cirrhotic patients with or without hepatocellular carcinoma: a comparative study. Hepatology. 1997;25:1485-9.

15. Fung J, Marsh W. The quandary over liver transplantation for hepatocellular carcinoma: the greater sin? Liver Transpl. 2002;8:775-7.

16. Gondolesi G, Muñoz L, Matsumoto C, Fishbein TM, Sheiner P, Emre S, Miller C, Schwartz ME. Hepatocellular carcinoma: a prime indication for living donor liver transplantation. J Gastrointest Surg. 2002;6:102-7.

17. Gondolesi GE, Roayaie S, Munoz L, Kim-Schluger L, Schiana T, Fishbein TM, Emre S, Miller CM, Schwartz ME. Adult living donor liver transplantation for patients with hepatocellular carcinoma extending UNOS priority criteria. Ann Surg. 2004;239:142-9.

18. Herrero JI, Sangro B, Quiroga J, Pardo F, Herraiz M, Cienfuegos JA, Pietro J. Influence of tumor characteristics on the outcome of liver transplantation among patients with liver cirrhosis and hepatocellular carcinoma. Liver Transpl. 2001;7:631-6.

19. Herrero JI, Sangro B, Pardo F, Quiroga J, Iñarrairaegui M, Rotellar F, Montiel C, Alegre F, Prieto J. Liver transplantation in patients with hepatocellular carcinoma across Milan criteria. Liver Transpl. 2008;14:272-8.

20. Hwang S, Lee SG, Joh JW, Suh KS, Kim DG. Liver transplantation for adult patients with hepatocellular carcinoma in Korea: comparison between cadaveric donor and living donor liver transplantations. Liver Transpl. 2005;11:1265-72.

21. Iwatsuki S, Starzl TE, Sheahan DG, Yokoyama I, Demetris AJ, Todo S, Tzakis AG, Van Thiel DH, Carr B, Selby R, et al. Hepatic resection versus transplantation for hepatocellular carcinoma. Ann Surg. 1991;214:221-8.
22. Jonas S, Bechstein WO, Steinmüller T, Herrmann M, Radke C, Berg T, Settmacher U, Neuhaus P. Vascular invasion and histhopathologic grading determine outcome after liver transplantation for hepatocellular carcinoma in cirrhosis. Hepatology. 2001;33:1080-6.

23. Kim RD, Nazarey P, Katz E, Chari RS. Laparoscopic staging and tumor ablation for hepatocellular carcinoma in Child $\mathrm{C}$ cirrhotics evaluated for orthotopic liver transplantation. Surg Endosc. 2004;18:39-44.

24. Klintmalm GB. Liver transplantation for hepatocellular carcinoma: a registry report of the impact of tumor characteristics on outcome. Ann Surg. 1998;228:479-90.

25. Kneteman N, Oberholzer J, Al Saghier M, Meeberg GA, Blitz M, Ma MM, Wong WW, Gutfreund K, Mason AL, Jewell LD, Shapiro AM, Bain VG, Bigam DL. Sirolimus-based immunosuppression for liver transplantation in the presence of extended criteria for hepatocellular carcinoma. Liver Transpl. 2004;10:1301-11.

26. Lee SG, Hwang S, Moon DB, Ahn CS, Kim KH, Sung KB, Ko GY, Park KM, Ha TY, Song GW. Expanded indication criteria of living donor liver transplantation for hepatocellular carcinoma at one large-volume center. Liver Transpl. 2008;14:935-45.

27. Li J, Yan LN, Yang J, Chen ZY, Li B, Zeng Y, Wen TF, Zhao JC, Wang WT, Yang $\mathrm{JY}, \mathrm{Xu}$ MQ, Ma YK. Indicators of prognosis after liver transplantation in Chinese hepatocellular carcinoma patients. World J Gastroenterol. 2009 15:4170-6.

28. Llovet JM, Fuster J, Bruix J; Barcelona-Clinic Liver Cancer Group. The Barcelona approach: diagnosis, staging, and treatment of hepatocellular carcinoma. Liver Transpl. 2004;10(2 Supl 1):S115-20.

29. Llovet JM, Bruix J, Fuster J, Castells A, Garcia-Valdecasas JC, Grande L, Franca A, Brú C, Navasa M, Ayuso MC, Solé M, Real MI, Vilana R, Rimola A, Visa J, Rodés J. Liver transplantation for small hepatocellular carcinoma: the tumornode-metastatsis classification does not have prognostic power. Hepatology. 1998;27:1572-7.

30. Llovet JM, Bruix J, Gores GJ. Surgical resection versus transplantation for early hepatocellular carcinoma: clues for the best strategy. Hepatology. 2000;31:1019-21.

31. Llovet JM, Burroughs A, Bruix J. Hepatocellular carcinoma. Lancet. 2003;362:1907-17.

32. Llovet JM, Bustamenate J, Castells A, Vilana R, Ayuso M del C, Sala M. Natural hystory of untreated nonsurgical hepatocellular carcinoma: rationale for the design and evaluation of therapeutics trials. Hepatology. 1999;29:62-7.

33. Llovet JM, Fuster J, Bruix J. Intention-to-treat analysis of surgical treatment for early hepatocellular carcinoma: resection versus transplantation. Hepatology. 1999;30:1434-40.

34. Llovet JM, Schwartz M, Mazzaferro V. Resection and liver transplantation for hepatocellular carcinoma. Semin Liver Dis. 2005;25:181-200.

35. Majeed TA, Wai CT, Rajekar H, Lee KH, Wong SY, Leong SO, Singh R, Tay $\mathrm{KH}$, Chen J, Tan KC. Experience of the transplant team is an important factor for posttransplant survival in patients with hepatocellular carcinoma undergoing living-donor liver transplantation. Transplant Proc. 2008;40:2507-9.

36. Makuuchi M, Sano K. The surgical approach to HCC: our progress and results in Japan. Liver Transpl. 2004;10(2 Supl 1):S46-S52.

37. Marsh JW, Dvorchik I. Liver organ allocation for hepatocellular carcinoma: are we sure? Liver Transpl. 2003;9:693-6.

38. Mazzaferro V, Llovet JM, Miceli R, Bhoori S, Schiavo M, Mariani L, Camerini T, Roayaie S, Schwartz ME, Grazi GL, Adam R, Neuhaus P, Salizzoni M, Bruix J, Forner A, De Carlis L, Cillo U, Burroughs AK, Troisi R, Rossi M, Gerunda GE, Lerut J, Belghiti J, Boin I, Gugenheim J, Rochling F, Van Hoek B, Majno P; Metroticket Investigator Study Group. Predicting survival after liver transplantation in patients with hepatocellular carcinoma beyond the Milan criteria: a retrospective, exploratory analysis. Lancet Oncol. 2009;10:35-43.

39. Mazzaferro V, Regalia E, Doci R, Andreola S, Pulvirenti A, Bozzetti A, Montalto F, Ammatuna M, Morabito A, Gennari L. Liver transplantation for the treatment of small hepatocellular carcinomas in patients with cirrhosis. N Engl J Med. 1996;334:693-9.

40. Moya A, Berenguer M, Aguilera V, Juan FS, Nicolás D, Pastor M, López-Andujar R, Rayón M, Orbis F, Mora J, De Juan M, Carrasco D, Vila JJ, Prieto M, Berenguer J, Mir J. Hepatocellular carcinoma: can it be considered a controversia indication for liver trasnplanation in centers with high rates of hepatiotis C? Liver Transplant. 2002;8:1020-7.

41. Neuhaus P, Jonas S, Bechstein WO, Wex C, Kling N, Settmacher U, al-Abadi H Liver transplantation for hepatocellular carcinoma. Transplant Proc. 1999;31:469-1.

42. Onaca N, Davis GL, Goldstein RM, Jennings LW, Klintmalm GB. Expanded criteria for liver transplantation in patients with hepatocellular carcinoma: a report from the International Registry of Hepatic Tumors in Liver Transplantation. Liver Transpl. 2007;13:391-9.

43. Penn I. Hepatic transplantation for primary and metastic cancers of the liver. Surgery. 1991;110:726-34.

44. Ringe B, Pichlmayr R, Wittekind C, Tusch G. Surgical treatment of hepatocellular carcinoma: experience with liver resection and transplantation in 198 patients. World J Surg. 1991;15:270-85. 
45. Roayaie S, Frischer J, Emre SH, Fishbein TM, Sheiner PA, Sung M, Miller CM, Schwartz ME. Long-term results with multimodal adjuvant therapy and liver transplantation for the treatment of hepatocellular carcinoma larger than 5 centimeters. Ann Surg. 2002;235:533-9.

46. Roayaie S, Schwartz JD, Sung MW, Emre SH, Miller CM, Gondolesi GE, Krieger NR, Schwartz ME. Recureence of hepatocellular carcinoma after liver transpl:patterns and prognosis. Liver Transpl. 2004;10:534-40.

47. Roberts MS, Angus DC, Bryce CL, Valenta Z, Weissfeld L. Survival after liver transplantation in the United States: a disease-specific analysis of the UNOS database. Liver Transpl. 2004;10:886-97.

48. Rode A, Bancel B, Douek P, Chevallier M, Vilgrain V, Picaud G, Henry L, Berger F, Bizollon T, Gaudin JL, Ducerf C. Small nodule detection in cirrhotic livers: evaluation with US, spiral CT and MRI and correlation with pathologic examination of explanted liver. J Comput Assist Tomogr. 2001;25:327-36.

49. Ryder SD; British Society of Gastroenterology. Guidelines for the diagnosis and treatment of hepatocellular carcinoma (HCC) in adults. Gut. 2003;52(Suppl 3):iiil-8.

50. Santoyo J, Suarez MA, Fernádez-Aguilar JL, Jiménez M, Perez Daga JA, Sánchez-Perez B, Gonzalez Poveda I, Gonzalez-Sanchez A, Ramírez C, de la Fuente A Liver transplant results for hepatocellular carcinoma applying strict preoperative selection criteria. Transplant Proc. 2005;37:1488-90.

51. Sauer P, Kraus TW, Schemmer P, Mehrabi A, Stremmel W, Buechler MW, Encke J. Liver transplantation for hepatocellular carcinoma: is there evidence for expanding the selection criteria? Transplantation. 2005;80 (1 Suppl):S105-8.

52. Scwartz M. Liver transplantation in patients with hepatocellular carcinoma. Liver Transpl. 2004;10(2 Supl 1):S81-S85.

53. Silva M, Moya A, Berenguer M, Sanjuan F, López-Andujar R, Pareja E, Torres-Quevedo R, Aguilera V, Montalva E, De Juan M, Mattos A, Prieto M, Mir J. Expanded criteria for liver transplanation in patients with cirrhosis and hepatocellular carcinoma. Liver Transpl. 2008;14:1449-60.

54. Soejima Y, Yoshizumi T, Uchiyama H, Aishima S, Terashi T, Shimada M, Maehara Y. Extended indication for living donor liver transplantation in patients with hepatocellular carcinoma. Transplantation. 2007;83:893-9.

55. Steingruber IE, Mallouhi A, Czermak BV, Waldenberger P, Gassner E, Offner F, Chemelli A, Koenigsrainer A, Vogel W, Jaschke WR. Pretransplantation evaluation of the cirrhotic liver with explantation correlation: accuracy of CT arterioportography and digital subtraction hepatic angiography in revealing hepatocellular carcinoma. Am J Roentgenol. 2003;181:99-108.

56. Stoker J, Romijn MG, de Man RA, Brouwer JT, Weverling GJ, van Muiswinke JM, Zondervan PE, Laméris JS, Ijzermans JN. Prospective comparative study of spiral computer tomography and magnetic resonance imaging for detection of hepatocellular carcinoma. Gut. 2002;51:105-7.
57. Takada Y, Ito T, Ueda M, Sakamoto S, Haga H, Maetani Y, Ogawa K, Ogura Y, Oike F, Egawa H, Uemoto S. Living donor liver transplantation for patient with HCC exceeding the Milan criteria: a proposal of expanded criteria. Dig Dis. 2007;25:299-302.

58. Takada Y, Uemoto S. Liver transplantation for hepatocellular carcinoma: the Kyoto experience. J Hepatobiliary Pancreat Sci.2010;17:527-32.

59. Tan CK, Gores GJ, Steers JL, Porayko MK, Hay JE, Rakela J, Wiesner RH, Krom RA. Orthotopic liver transplantation for preoperative early-stage hepatocellular carcinoma. Mayo Clinic Proc. 1994;69:509-14

60. Teefy SA, Hildeboldt CC, Dehdashti F, Siegel BA, Peters MG, Heiken JP, Brown JJ, McFarland EG, Middleton WD, Balfe DM, Ritter JH. Detection of primary hepatic malignancy in liver candidates: prospective comparison of CT, MR imaging, US and PET. Radiology. 2003;226:533-42.

61. Todo S, Furukawa H, Tada M; Japanese Liver Transplantation Study Group. Extending indication: role of living donor liver transplantation for hepatocellular carcinoma. Liver Transpl. 2007;13(11 Suppl 2):S48-54

62. Xiao L, Fu ZR, Ding GS, Fu H, Ni ZJ, Wang ZX, Shi XM, Guo WY. Liver transplantation for hepatitis B virus-related hepatocellular carcinoma: one center's experience in China. Transplant Proc. 2009;41:1717-21.

63. Yao FY, Bass NM, Nikolai B, Davern TJ, Kerlan R, Wu V, Ascher NL, Roberts JP. Liver transplantation for hepatocellular carcinoma: analysis of survival according to intention-to-treat principle and dropout from the waiting list. Liver Transpl. 2002;8:873-83

64. Yao FY, Ferrell L, Bass NM, Watson JJ, Bacchetti P, Venook A, Ascher NL, Roberts JP. Liver transplantation for hepatocellular carcinoma: expansion of the tumor size limits does not adversely impact survival. Hepatology. 2001;33:1394 403

65. Yao FY, Roberts JP. Applying expanded criteria to liver transplantation for hepatocellular carcinoma: too much too soon, or is now the time. Liver Transpl. 2004;10:919-21.

66. Yao FY, Xiao L, Bass NM, Kerlan R, Ascher NR, Roberts JP. Liver transplantationm for hepatocellular carcinoma: validation of the UCSF-enpanded criteria based on preoperative imaging. Am J Transpl. 2007:7:2587-96.

67. Yao FY. Expanded criteria for liver transplantation in patients with hepatocellular carcinoma. Hepatol Res. 2007;37 Suppl 2:S267-74.

68. Zavaglia C, De Carlis L, Alberti AB, Minola E, Belli LS, Slim AO, Airoldi A, Giacomoni A, Rondinara G, Tinelli C, Forti D, Pinzello G. Predictors of longterm survival after liver transplantation for hepatocellular carcinoma. Am J Gastroenterol. 2005;100:2708-16.

Received 19/4/2012 Accepted 18/7/2012 